\title{
THE ROLE OF THE STATE IN INDUSTRIAL DISPUTE SETTLEMENT MECHANISMS IN NIGERIA
}

\author{
DUMEBI, Anthony Ideh(PhD ${ }^{1}$; SHONUGA,Adedoyinsola Olajumoke ${ }^{2}$ \\ Department of Employment Relations and Human Resource Management, Faculty of Management Sciences, \\ University of Lagos, Nigeria, ${ }^{1,2}$ \\ E-mails: ${ }^{1}$ tonydum68@yahoo.com; ${ }^{2}$ candysho2001@yahoo.com \\ DOI: $10.36108 /$ ljerhrm/8102.01.0160
}

\begin{abstract}
Disputes and dispute resolutions are part and parcel of any functional industrial relations system. Therefore, the need to resolve them equitably, efficiently and effectively for the benefit of the actors is of paramount importance. The objective of this study is to examine the State intervention in dispute settlement and its contributions in peaceful resolution of disputes in Nigeria. The paper adopted the qualitative research approach. Relevant data were collected from the Lagos offices of the Federal Ministry of Labour and Employment, the Industrial Arbitration Panel and the National Industrial Court. The study found that the various pieces of legislation enacted by the State have positively impacted on the settlement of Industrial Disputes in Nigeria. However, it was observed that despite the positive contributions, there are still some areas for improvement. The study therefore made the following recommendations; that the powers of the Minister of Labour and Employment should be restricted to create an enabling industrial relations environment for the actors and that the parties to disputes should be allowed the choice of which method of disputes settlement to use among other recommendations.
\end{abstract}

Key words: Arbitration, Dispute, Nigeria, Settlement Mechanism, State

\section{Introduction}

The State understands the importance of settlement of industrial disputes and has from time to time made pronouncements in setting framework for settlement of trade disputes whenever they arise. To be sure that disputes do not degenerate beyond the reasonably accepted level; the State intervenes mainly to protect the interest of the public against the negative effects of the dispute which could bring about detrimental economic and social change. Barbash (1979) as cited in Iwuji (1987) argues that when the costs of disputes seem to be borne more by the society at large or by groups outside of the immediate bargaining relationship, the State steps in to try to create a new equilibrium of forces.

Public policy towards industrial relations up to 1968 was based on the principle of freedom and non-interference (voluntarism).The principle of voluntarism recognises the freedom of workers and employers to manage labour affairs within the confines of the legal framework without interference from the State. Although, the Trade Disputes (Arbitration and Inquiry) Ordinance of 1941 made provision for the use of conciliation, arbitration and inquiry in settlement of trade disputes, it also recognised the right of the parties in the dispute to decide which of the settlement methods to adopt. The stakeholders bore the primary responsibility of resolving their disputes using the mechanisms of negotiation, collective agreement, and, where necessary, industrial action (Agomo, 2011). Under this regime, government intervention in trade disputes was based on invitation and by the consent of the parties to the dispute. This means that, the Minister of Labour and Employment must obtain the consent of the parties in prescribing any of the methods provided by the Ordinance. Under the 1941 Ordinance, the award or decision of any of the methods was not binding on either party to a dispute (Fashoyin, 1981).

Disputes and dispute resolutions are part and parcel of any functional industrial relations system. As noted by Sarowar (2015), conflict or disputes arise in any industrial setting due to terms and conditions of employment contract, working conditions, wage structure and financial interest among others. However, the need to resolve them equitably, efficiently and effectively for the benefit of the actors is of paramount importance. In resolving disputes, there are various options open to the actors ranging from internal to external mechanisms, formal and informal, all in the public interest.

Fashoyin (1981) identified two distinct categories of dispute settlement tactics: Containment Approach: these are disputes that are amicably settled; and Eliminationist Approach: these are disputes in which the proscription order was invoked. However, a third category, the Intimidationist Approach, could be added and this involves where disputes were settled by an act of threat and coercion of the workers by agents of the State such as the Police, the State Security Services and or the Anti-corruption agencies. This is supported by Otobo's (2000) assertion that, government quite often use intelligence organisations, police and soldiers to break strikes, physical harassment and intimidation, or sending some strikers to tribunals or courts for trial. 
In Nigeria, the legal framework for settlement of trade disputes can be found in the following Acts; the Trade Dispute Act 1976 as amended, the Trade Dispute (Essential Services) Act 1976 as amended, the National Industrial Court Act 2006, and the Constitution of the Federal Republic of Nigeria (Third Alteration) Act 2010. It is therefore imperative for one to take a cursory look at how these various interventions by the state have impacted on the dispute settlement mechanisms in Nigeria.

\subsection{Statement of the Problem}

Although, there have been various studies (Arputharaj \& Gayatri, 2014; Essien, 2014; Katuwal, 2011; Sarowar, 2015) on dispute settlement mechanisms in Nigeria and other countries, there are yet a few studies that have focused on examining the influence of State intervention in dispute settlement mechanisms in Nigeria . For example, while Essien (2014) examines the status of Industrial Arbitration Panel (IAP) in dispute settlement in Nigeria and concludes that there is need to re-shape IAP for its continued relevance in dispute settlement, Sarowar (2015) states that in Bangladesh, the Labour Act does not clarify the procedure to settle an industrial dispute where no collective bargaining agents exist. Also, Katuwal (2011) opines that in spite of the statutory mechanism put in place for prevention and settlement of industrial disputes, there are still common industrial problems in Nepal. On the other hand, Arputharaj and Gayatri (2014) provide informative guide to the practical aspects of industrial disputes for those firms that want to establish businesses or factories in India. The above cited studies show that there exist gaps in literature and there are still dearth of research that focus on appraising the influence of the State in dispute settlement mechanism in Nigeria. The Nigerian government has introduced some changes in Nigerian industrial relations space with reviews of various pieces of legislations that govern employment relations. It is relevant for an examination of how these changes have impacted on dispute settlement mechanism in Nigeria and this study seeks to fill the identified gap in literature.

\subsection{Objectives of the Study}

The main objective of this study is to examine the role of the State in the use of dispute settlement mechanisms in Nigeria while the specific objectives are to examine the State intervention in disputes settlement and its contributions towards the peaceful resolution of the disputes. Also, the study aims at espousing some practical suggestions about the effectiveness or otherwise of the dispute settlement machinery in Nigeria.

\section{Literature Review}

\section{Industrial Dispute and Settlement Mechanism}

The cost of industrial dispute to the industrial relations actors is high. Every actor, particularly the State works out new approach and strategy to reduce the impact of industrial dispute on the economy. Since commentators have acclaimed the inevitability of conflict in the industry, it becomes imperative that emphasis should be on management of conflict and resolution of disputes in the organisation. As noted by (Arputharaj and Gayatri, 2014) conflict or dispute resolution is an essential part of any well-functioning labour market and industrial relations system. If the Government fails to intervene in the dispute situation promptly, it may escalate and inflict serious damage on the parties or the general public that are not involved in the conflict. Obviously, the State plays a more interventionist role in industrial relations today than in the past. During the colonial era up to the period before the Nigerian civil war, there was no strict legal framework for the settlement of trade disputes. However, the civil war period forced the government to abandon the voluntary principle of dispute settlement for the interventionist principle through the enactment of the Trade Dispute (Emergency Provision) Acts of 1968 and 1969 which provided machinery for settling trade disputes. In addition to the earlier provisions in the legislative framework, Industrial Arbitration Panel (IAP) and the National Industrial Court (NIC) were established by the Trade Disputes Act No 7 of 1976.

The Nigeria government has in response to making sure that there is industrial peace, created a clear cut course of action and ways of resolving industrial dispute whenever it occurs. In other words, when there is a trade dispute, there are standard policies laid down by the State to ensure peaceful settlement of such disputes.

These could be found in the following pieces of legislation:

- The Trade Disputes Act No. 7 of 1976

- The Trade Disputes (Essential Services) Act No. 23 of 1976

- Trade Disputes (Amendment) Act No. 54 of 1977

- Trade Disputes (Essential Services) Amendment Act No. 69 of 1977

- Trade Disputes (Delegation of Certain Statutory function) Order 1984

- Trade Disputes (Amendment) Act No. 39 of 1988 
- $\quad$ Trade Dispute (Amendment) Act No. 47 of 1992

- The National Industrial Court Act 2006

- The Constitution of the Federal Republic of Nigeria (Third Alteration) Act 2010

Due to the inevitability of disputes in the workplace, it becomes imperative that clear cut ways of resolving them when they occur should be clearly stated. The State through various pieces of legislation has provided a clearly defined procedure for the peaceful resolution of trade disputes whenever they occur either by means of the internal machinery and when the internal machinery fails, the use of the statutory external machinery of mediation, conciliation, arbitration (Industrial Arbitration Panel) and industrial court can be invoked. The standard framework drawn by the state is as discussed below.

\section{Standard Framework for Dispute Resolution}

Disputes settlement in Nigeria as earlier stated, takes place at two levels, using the internal machinery which is collectively negotiated and the external machinery which involves the intervention of a third party as provided by the State through the various Acts. The statutory machinery is invoked when the internal machinery fails.

\section{Internal or Voluntary Disputes Settlement Mechanism}

The internal disputes settlement mechanism involves the use of the grievance procedures as set out in an organisation's rule book which includes collective bargaining. The Trade Dispute Act 1976 recognises the principle of free collective bargaining and voluntary settlement of trade disputes (Agomo, 2011). Collective bargaining according to Agomo (2011) is collective dialogue, or collective negotiation between the employer's representatives and the workers' representative with a view to reaching a collective agreement on issues under negotiation.

Section 2 of the Trade Dispute Act provides that "where there is any collective agreement for the settlement of trade disputes; at least three copies of the said agreement shall be deposited by the parties thereto with the minister

- In case of a collective agreement entered into on or after the date of commencement of this Act, within thirty days of that.

- In case of the collective agreement entered into on or after the date of commencement of this Act, within fourteen days of the execution thereof;

Any person who fails to deposit copies of the said agreement within the period prescribed in the foregoing provisions of this subsection shall be guilty of an offence under this Act and shall on conviction be liable to a fine of $\mathrm{N} 100$ (One hundred Naira only).

Section (3) (1) provides;

'If there exists agreed means for settlement of the dispute apart from this Act, whether by virtue of the provisions of any agreement between organisations representing the interest of employers and organisation of workers or any other agreement, the parties to the dispute shall first attempt to settle it by that means'

\section{External Disputes Settlement Mechanisms}

The external dispute settlement procedure is provided for in the Trade Disputes Act 1976 and the subsequent amendments. The law encourages the workers and their employers to make effort at settling their disputes using the voluntary procedures as specified in their procedural agreement. This could be collective bargaining as pointed out earlier.

Section 3(1) of the Trade Disputes Act, provides that "if there exist agreed means for settlement of the dispute between organisations representing the interests of employers and organisation of workers or any other agreement, the parties to the dispute shall first attempt to settle it by that means". According to Fajana (2006), voluntary settlement through collective bargaining often fails due to the non-existence of sufficient trust, sincerity and goodwill between management, and union leaders. The Trade Dispute Act 1976 envisaged the failure of the voluntary settlement procedures and provided in section 3(2), that if the attempt to settle the dispute as provided in section (1) fails, the parties shall resort to the external dispute settlement procedures using the under listed formal statutory institutions:

- Mediation

- Conciliation

- Arbitration (Industrial Arbitration Panel)

- Industrial Court (National Industrial Court)

- Board of Inquiry 


\section{Methodology}

The paper adopted the qualitative research approach. Content analysis was used in the analysis of the performance of the various dispute settlement mechanisms. The data used were taken from both primary and secondary sources. Relevant data were collected from the Lagos offices of the Federal Ministry of Labour and Employment, the Industrial Arbitration Panel and the National Industrial Court. The secondary sources include journals, reports, different websites and data from official and unofficial sources.

The study commenced with the introductory section followed by a brief review of literature on industrial dispute and settlement mechanism and the standard framework for dispute resolution which covered the internal and external mechanisms. This is followed by discussion and analysis of data on the various external dispute settlement mechanisms. The final part x-rayed the study's perspective of public policy on dispute settlement mechanisms, conclusion and recommendations.

\section{Discussion and Analyses}

\section{Mediation}

This is the first step of external settlement mechanism. It is a provision of The Trade Disputes Act that when the internal machinery fails to resolve any dispute, the parties involved should resort to Mediation. Fashoyin (1992) observes that mediation is sparingly used by employers in the private sector especially in resolving interpersonal, procedural and substantive disputes.

Section 3 (2) of the Trade Disputes Act 1976 provides that if internal machinery fails or if there is no internal machinery for settlement of trade dispute, the disputing parties shall within seven days of the failure of negotiation or seven days of the existence of the dispute if no machinery exists, come together either by themselves or their representatives, under the presidency of a mediator mutually agreed upon and appointed by or on behalf of the parties with a view to amicably resolving the dispute.

Should any of the parties have the intention to pursue the matter further in the event of failure to settle the dispute amicably, such party is required to declare a trade dispute and inform in writing the Ministry of Labour and Employment within fourteen days of the failure to settle the dispute.

According to Fashoyin (1992), the machinery has the prospect of assisting the parties to reach agreement if it is applied in exploring common areas of likely agreement. Its use is not common in Nigeria for the following reasons:

- The failure of the Ministry of Labour and Employment to enforce its use as provided in the Act and also its failure to set up a pool of Mediators that can be called upon by the parties

- The cost attached to the use of Mediators as parties are meant to pay for the services of the Mediator

- The difficulty in arriving at a choice of a Mediator by the parties

- The Mediator is successfully used for issues that would result in colossal damage or cost if a solution is not found quickly.

\section{Conciliation}

If a Mediator is unable to reach a settlement within seven days of his appointment, the dispute shall be reported to the Minister in writing by any of the parties within three days of the end of seven days. The Minister shall appoint a fit person as a Conciliator. Although, the Act makes provision for the appointment of a fit person by the Minister of Labour and Employment, it is usual for the Minister to appoint one of his officers to serve as a Conciliator (Anyim, 2009; Fashoyin, 1992).

Section 7(3) of the Trade Disputes Act provides that if within seven days of the appointment of a Conciliator, and the person so appointed is able to reach settlement, the Conciliator shall report the fact to the Minister and shall forward to him a memorandum of the terms of the settlement signed by the representatives of the parties, and as from the date the memorandum was signed (or such earlier or later date as may be specified therein), the terms recorded therein shall be binding on the employers and workers to whom those terms relate.

However, Section 7 (5) provides that if a settlement of the dispute is not reached within seven days of his appointment or if, after attempting negotiation with the parties, he is satisfied that he will not be able to bring about settlement by means thereof; the Conciliator shall send a report to the Minister. According to Fashoyin (1992), conciliation is the next most commonly used form of third-party intervention in Nigeria after collective bargaining. This position agrees with the finding in the study by Anyim (2009) which revealed that conciliation as trade dispute settlement machinery has higher level of usage than other external machineries for disputes settlement in Nigeria. 


\section{Arbitration}

Arbitration into industrial disputes in Nigeria is conducted by the Industrial Arbitration Panel (IAP). Industrial Arbitration Panel (IAP) was set up by the Trade Dispute Decree of 1969 as a tripartite agency. The word arbitration according to Otobo (2000) is derived from the Latin word arbitrari, meaning 'to give judgment' or 'to make a decision'. Trade disputes are usually referred to the Arbitration Panel by the Minister within fourteen days of the receipt of report from a Conciliator.

The IAP is made up of a chairman, a vice chairman, and not less than ten other members appointed by the Minister. Out of the ten members, two each are nominated by the employers and labour unions respectively. IAP has jurisdiction for trade disputes and does not handle individual or disputes that bother on human rights.

When the Minister refers any dispute to the panel, the Chairman of the panel would constitute an Arbitration Tribunal made up of the following;

- A sole Arbitrator

- A single Arbitrator to be assisted by two or more assessors to be nominated on equal basis from the panel of employers and workers representatives

- One or more Arbitrators nominated by or on behalf of the employers and an equal number of arbitrators nominated by the workers concerned with the chairman or vice chairman presiding

An Arbitration Tribunal has within twenty one days or such longer period, as the Minister may allow in particular case, to make its award. The award of IAP is communicated to the Minister and not to the parties affected. It is the Minister that releases the award of the tribunal to the parties or their representatives. Either of the parties to the dispute have within seven days of release of the award to the parties to raise notice of objection to the Minister and if no notice is given within the specified days, the Minister shall publish in the Federal Gazette a notice confirming the award and the award shall be binding on the employers and workers to whom it relates with effect from the date of the award or such earlier or later date as may be specified in the award.

However, under certain circumstances, the Minister may refer the award back to the arbitration tribunal for reconsideration if he so desires. Although, the Act did not specify what constitutes the desirability of the Minister in referring back the awards, Fashoyin (1992) and Anyim (2009) state that the Minister may refer the award back to the Arbitration Tribunal for reconsideration if he observes a contravention of any of the public policies or interests by the award of the panel. Fashoyin (1992) observes that arbitration process has gained increasing popularity since it was introduced in the late 1960s and that trade unions seem to have more preference for arbitration to conciliation, especially when it involves interest disputes and economic issues.

\section{Table 1: CASES REFERRED TO IAP LAGOS OFFICE FROM 2004 TO 2012}

\begin{tabular}{|c|c|c|c|c|}
\hline S/N & YEAR & $\begin{array}{c}\text { NO. OF CASES } \\
\text { REFERRED }\end{array}$ & $\begin{array}{c}\text { NO. OF CASES } \\
\text { DISPOSED }\end{array}$ & $\begin{array}{c}\text { NO. OF CASES } \\
\text { PENDING }\end{array}$ \\
\hline 1 & 2004 & 7 & 7 & Nil \\
\hline & 2005 & 4 & 4 & Nil \\
\hline 3 & 2006 & 5 & 5 & Nil \\
\hline 4 & 2007 & 4 & 3 & Nil \\
\hline 5 & 2008 & 6 & 6 & Nil \\
\hline 6 & 2009 & 7 & 7 & Nil \\
\hline 7 & 2010 & 1 & 1 & 2 \\
\hline 8 & 2011 & 7 & 5 & 2 \\
\hline 9 & 2012 & 2 & Nil & \\
\hline
\end{tabular}

Source: IAP Lagos office (2012)

A major challenge of IAP is that of relative delay in disposing-off cases brought before it. This observation is in line with Anyim (2009) which states that although Section 12 of the Trade Disputes Act requires IAP to make its award within 21 days but this could be extended to 42 days with the approval of the Minister, Experience had shown that this time frame is hardly complied with. The delay can also be observed from Table 1 that, of the four cases referred to the Lagos office of IAP in 2007, one of the cases was outstanding in 2012. As stated by a Registry staff of the IAP, that 'the final hearing on the case took place in 2012 and also that out of the seven cases referred in 2011, two remained unresolved till 2012'.

Despite the identified shortcoming, it must be noted that IAP has made some landmark decisions in its awards particularly in the interpretation of section 12 (4) of the Trade Unions Act, as amended by Trade Unions (Amendment) Act of 2005. The section provides that membership of trade unions by employees shall be voluntary 
and that no employee shall be forced to join any trade union or be victimised for refusing to join or remain a member. This section has been misunderstood by researchers, union leaders, writers, and industrial relations practitioners alike. Hence the different interpretations pushed by the parties. For instance, Danesi (2010) argues that the Trade Union (Amendment) Act of 2005 restated the voluntarism principle of the Nigerian industrial relations system and the introduction of a multi-union system.

It may also be based on this misinterpretation of section 12 (4) of the Trade Unions Act (as amended), that made the National Union of Petroleum and Natural Gases Workers (NUPENG) to attempt the unionisation of the workers of Polmaz Nig Limited a stevedoring company supplying labour services to Chevron for operations in Escravos (near Warri) in Delta State, Nigeria. This action led to a trade dispute between the Maritime Workers Union (MWU) and NUPENG. In this case brought before IAP for a settlement, it was held that the Trade unions (Amendment) Act 2005 did not abolish the "jurisdictional Scope of Unions" enshrined in the Principal Act (part $\mathrm{B}$, third schedule). The Tribunal was of the opinion that "if the intention of the legislature was to abolish the jurisdictional scope of trade unions, the law would have expressly repealed the third schedule as it did in respect of some other provisions". The National Industrial Court (NIC) in an appeal filed by NUPENG upheld the award of the IAP on June 21, 2012. The award by IAP and the judgment by the NIC have therefore put to rest the speculation that the Trade Union (Amendment) Act 2005 has abolished the jurisdictional scope of trade unions.

\section{The National Industrial Court (NIC)}

The NIC was established in 1976 by the Trade Disputes Act 1976. However, the Court was first inaugurated on 5 June, 1978 and has turned out a number of judgments (Odumosu, 1986). The data on the number of judgments and rulings are presented in Table 2.

The face of NIC has changed with the enactment of the National Industrial Court Act, 2006 and the Constitution of the Federal Republic of Nigeria (Third Alteration) Act, 2010. Three issues necessitated the need for the NIC Act, 2006:

- The question of constitutionality of its jurisdiction and power. According to Agomo (2011), the confusion arose because the Trade Disputes (Amendment Act) 1992 that enlarged the jurisdiction of the NIC by including inter- and intra-union disputes did not equally amend the definition of trade dispute in the main Act

- Composition of the court was a challenge as the president was required to preside over all sittings of the court. The implication is that in the absence of the president for whatever reason, the court would not sit

- The appointment of other members of the court by the Minister of Labour and Employment and the appointment of non-lawyers as members of the court created a problem of acceptance by the judiciary, as it negates the principles of separation of powers.

The NIC from 1978 to 2014 had settled a number of trade disputes as shown in Table 2

Table 2: JUDGMENTS AND RULINGS OF NIC FROM 1978 TO 2014

\begin{tabular}{|l|l|l|l|}
\hline YEAR & No. of judgments & No. of Rulings & Total \\
\hline 1978 to 2005 & 123 & 55 & 178 \\
\hline 2006 & 6 & 5 & 11 \\
\hline 2007 & 6 & 3 & 9 \\
\hline 2008 & 9 & 10 & 19 \\
\hline 2009 & 13 & 15 & 28 \\
\hline 2010 & 14 & 20 & 24 \\
\hline 2011 & 18 & 19 & 37 \\
\hline 2012 & 36 & 40 & 76 \\
\hline 2013 & 53 & 37 & 90 \\
\hline 2014 & 125 & 73 & 198 \\
\hline
\end{tabular}

Source: NIC, 2015

It can be observed from Table 2 that the number of ruling on cases handled by NIC from 2006 has been on the increase. Judgments and rulings in 2014 alone were more than those of 1978 to 2005 put together. This could be explained by the changes made by both the NIC Act 2006 and the constitution of Federal Republic of Nigeria (Third Alteration) Act 2010 on the composition of the judges and the expansion of the jurisdiction of the NIC. Some of the changes include the expansion of the jurisdiction of the NIC by the Constitution to include a wide range of areas that were before now not covered; the provision that individuals can now approach the Court unlike the pre-Act era when cases were either referred to it from IAP or by the Minister of Labour and Employment. 
Also, the provision that the Court can be properly constituted by the President of the Court without himself presiding and that the NIC shall be duly constituted if it consists of a single judge or not more than three judges as the President of the NIC may direct among other changes

\section{Board of Inquiry}

Disputes could be referred to the Board of Inquiry to look into the causes and circumstances of the disputes. It is more like a fact finding mission as it is a means of informing the government and members of the public regarding the facts and the underlining causes of a dispute where these are not easily noticeable and application of the appropriate machinery becomes difficult. Section 32 of the Trade Dispute Act gave the Minister of Labour and Employment the power to set up a Board of Inquiry to look into or investigate disputes and other employment problems. The duty of the Board is to make inquiry about a dispute and report back to the Minister about the findings and possibly make recommendations.

\section{Perspectives on Legal Framework for Dispute Settlement}

Public policy issues on settlement of trade disputes align with the position of Iwuji (1987) that the settlement procedures in most of the developing countries such as Nigeria are based on the prohibition of strikes and lockouts and on compulsory arbitration. This is done by the establishment of appropriate legal framework for the institution and practice of industrial relations. Also by encouraging the practice of collective bargaining; by making sure that where there is inadequate provision in the collective agreement, minimum standards for employment are set; by the provision of peace making services in form of voluntary assistance; and by authoritarian form where disputes between the parties seem to threaten national interests.

From observation, the government has in different ways made effort to create provisions aimed at advancing peaceful resolution of trade disputes. The laid down legal framework are intended to moderate the excesses of the industrial relations actors in their relationship.

The consequences of non-involvement of the State in settlement of trade disputes may be that dispute instead of being a means of inducing agreement might result in class warfare, dis-organisation, alienation and lifethreatening, gross inequalities in income and power, and damage to national economy (Iwuji, 1987). There has been strong government intervention in the use of disputes settlement mechanism since the enactment of Trade Disputes (Emergency) Act 1968.

The independence of the IAP and NIC had remained an issue. However, the Constitution of the Federal Republic of Nigeria (Third Alteration) Act 2010 has resolved the independence of NIC by removing the appointment of the President and judges of the court from the Minister of Labour and Productivity and now vested on the President of the Federation on the recommendation of the National Judicial Council (NJC) and by the confirmation of the Senate in the case of the President of the NIC.

For the IAP, it is the study's opinion that the Ministry of Labour and Employment should hands off all issues regarding the appointment of Arbitrators, referral of cases and the announcement of awards. This position is premised on the need to have a neutral and an unbiased umpire dealing with the sensitive issues of appointment of Arbitrators, announcement of awards and the like. Since the IAP is an institution of adjudication, appointments and control of the IAP should also be handled by the judiciary. The Minister should not get involved in the operations of the disputes settlement mechanism other than creating an enabling environment. This view point is based on the fact that the government is the single largest employer of labour in Nigeria and the involvement of the Minister of Labour and Employment as an agent of government is akin to presiding over ones case.

In like manner, the function of referral of cases and the announcement of awards should be taken from the executive arm of government and handed over to the judiciary. This position is in line with Adeogun (1976) argument that the awards of the IAP should become binding on the parties and that it should be up to the parties themselves to decide whether or not an appeal should be lodged with the NIC (as cited in Ubeku, 1983). Although, Ubeku (1983) argues that there is need for continued review of all awards by the Ministry of Labour because the IAP, sometimes out of enthusiasm, hands down decisions that are not in accord with practice in industry, it is this study's view that where the Minister thinks that an award is not in the interest of the nation and must be rejected, he can approach the NIC for judicial interpretation and pronouncement rather than personally taking such decision which could be tantamount to abuse of the powers of the office of the Minister. 


\section{Conclusion and Recommendations}

In conclusion, the government, in an attempt to maintain peaceful relations in Nigerian industrial relations system, has enacted several pieces of legislation starting with the Trade Disputes (Arbitration and Inquiry) Ordinance 1941 to the most recent Constitution of FRN (Third Alteration) Act, 2010 which has significantly altered the face of labour legislation and dispute settlement mechanism in Nigeria. The various pieces of legislation have positively impacted on the settlement of Industrial Disputes. However, despite the positive contributions, there are still some areas for improvements. Hence, the recommendations put forward by the study.

The study puts forward the following recommendations which will help to further strengthen the trade dispute settlement mechanisms in Nigeria.

- The appointment of conciliators should be made to follow the provisions of the Trade Disputes Act, 1976 that Conciliators should be fit and proper persons. The present regime where the Minister appoints staff of the Ministry that are not trained in the art of conciliation may not be in the best interest of the parties and the dispute settlement mechanism. The staff of the Ministry should undergo proper training in dispute resolution strategies if they are to acquire that status of "proper and fit persons" recommended by the Act.

- Government intervention is necessary to the extent that they set the rules of engagement. The powers of the Minister should be restricted to creating a favourable Industrial Relations environment for the Actors to operate. The Minister of Labour and Productivity should intervene to the extent of seeking legal interpretations from the NIC where he/she is of the opinion that the IAP award is not in national interest

- Parties to disputes should be allowed to make choice of which method of settlement to use. The straight jacket recommendation of the present procedure will not allow for quick dispensation of justice. If the choice of method is left with the parties to the dispute, their confidence in the chosen method and the outcome will increase.

- The use of Alternative Dispute Resolution (ADR) mechanism should be further enhanced. Although, the NIC Act provides that ADR centre can be set up within the premises of the Court, it will however be more robust if its existence goes beyond the Court premises.

- The fines imposed for breach of the provisions of the Acts should be reviewed as such amounts imposed cannot serve as a deterrent to any party that wants to breach the provisions of the Trade Disputes Act in the present time. For example, a fine of N100 imposed in section (2) of the Trade Disputes Act cited earlier in this work is not only inadequate but ridiculous in Nigeria of today. By the same token, the enforcement of the provisions of the Act should be diligently enforced to minimise the occurrence of disputes.

- The major limitation of the study is that it relied mostly on archival and theoretical data. Although it does not significantly affect the conclusions, it is however recommended that for future research, a more indepth study that seek the opinion of workers, their unions and employers in relations to the performance of the various dispute settlement mechanisms be carried out.

\section{References}

Adeogun, A. A. (1976). Towards a better system of settling trade disputes, Nigerian Law Journal, 10, 5

Agomo, C. K. (2011). Nigerian employment and labour relations law and practice, Lagos; Concept Publications Ltd

Anyim, F. C. (2009). A critique of trade disputes settlement mechanism in Nigeria: 1968 - 2004. Unpublished University of Lagos, Ph.D Thesis.

Arputharaj, M. J. \& Gayatri, R. (2014). A critical analysis on efficacy of mechanism to industrialdisputes resolution in India. International Journal of Current Research and Academic Review, 2(8), 328-344

Barbash, J. (1979). Collective bargaining and the theory of conflict. Paper presented at the $5^{\text {th }}$ World congress of IIRA, Paris, 3-7 September.

Danesi, R. (2011). Nonstandard work arrangements and the right to freedom of association in Nigeria", Paper Presented at IIRA Regional Conference, Lagos, 24 - 28 January

Essien, K. B. (2014). Re-shaping institutions for industrial dispute settlement in Nigeria: Perspectiveson the status of the industrial arbitration panel. International Journal of Research (IJR), 1(6), 463-476

Fajana, S. (2006). Industrial relations in Nigeria: Theory and features ( $3^{\text {rd }}$ edition), Lagos; Labofin

Fashoyin, T (1992). Industrial relations in Nigeria: Development and practice ( $2^{\text {nd }}$ ed.), Lagos; Longman Nigeria Ltd

Fashoyin, T. (1981). State regulation of trade disputes in essential services in Nigeria,Relations Industrielles/Industrial Relations, 36(1), 207 - 222; http://id.erudit.org/iderudit/029133ar

Federal Republic of Nigeria (1976), The Trade Disputes Act No. 7 of 1976

Federal Republic of Nigeria (1976). The trade disputes (Essential services) act No. 23 of 1976 
Federal Republic of Nigeria (1977). Trade disputes (Amendment) act No. 54 of 1977

Federal Republic of Nigeria (1977) Trade disputes (Essential services) amendment act No. 69 of 1977

Federal Republic of Nigeria (1984). Trade disputes (Delegation of certain statutory functions) order 1984

Federal Republic of Nigeria (1988). Trade disputes (amendment) act No. 39 of 1988

Federal Republic of Nigeria (1992). Trade dispute (amendment) act No. 47 of 1992

Federal Republic of Nigeria (2006). The national industrial court act 2006

Federal Republic of Nigeria (2010). The constitution of the Federal Republic of Nigeria (Third Alteration) Act 2010

Iwuji E. C. (1987). Settlement of trade disputes, in Otobo, D. and M. Omole (Ed), Readings in Industrial Relations in Nigeria, Lagos: Malthouse Publishing Ltd

Katuwal, S. B. (2011). Statutory mechanism of the prevention of industrial disputes in Nepal.International Journal of Business Management, Economics and Information technology, 3(2), 275-279

Odumosu, O. I. (1987). The trade union leader and resolution of industrial conflict, in Otobo, D. and M. Omole (Ed) Readings in Industrial Relations in Nigeria, Lagos, Malthouse Publishing Ltd.

Otobo D. (2000). Industrial Relations: Theory and Controversy, Lagos, Malthouse Press Ltd.

Sarowar, G. (2015). Industrial dispute settlement mechanism and its effectiveness inbangladesh: A legal study. Manarat International University Studies,4(1), 103-110

Ubeku A. K.(1983). Industrial Relations in Developing Countries: The Case of Nigeria: London, Macmillan Press. 